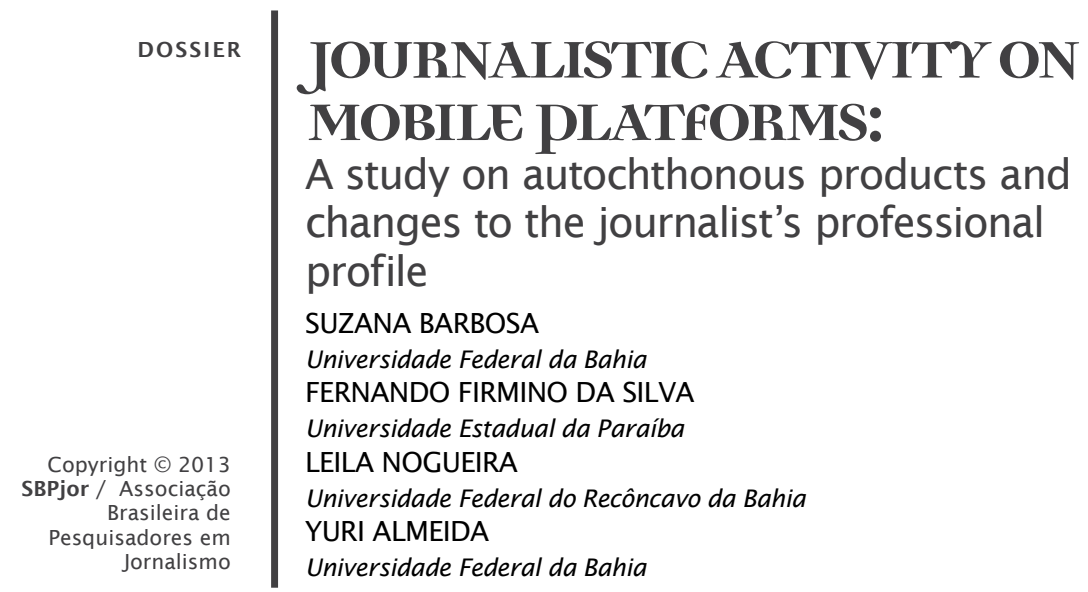

\begin{abstract}
This article is centred on a study of the empirical and theoretical-conceptual nature of autochthonous (original) products for tablets, with a horizontal multiplatform logic, integrating the web, tablets, smartphones and PDF and page flip versions of printed editions in a dynamic, multimedia continuum launched as part of journalistic organizations' strategies in compliance with journalistic convergence processes. The methodology includes a qualitative, empirical analysis of actual products ( $\mathrm{O}$ Globo a Mais, Estadão Noite and Folha10) conducted in an ad hoc exploratory manner, associated to semi-structured interviews with editors and reporters. The results indicate changes to the profile of the professionals involved with production strategies for tablets, inserting new elements in autochthonous product narratives. A 3.0 transposition was simultaneously identified, as the exclusive content for tablet products is transferred to other platforms at a later date.
\end{abstract}

Keywords: Journalistic convergence. Mobile journalism. Tablets. Autochthonous products. Journalists Statute.

\title{
A ATUAÇÃO JORNALÍSTICA EM PLATAFORMAS MÓVEIS Estudo sobre produtos autóctones e a mudança no estatuto do jornalista
}

RESUMO - Este artigo está centrado no estudo de caráter empírico e teórico-conceitual dos produtos autóctones (originais) para tablets, lançados como parte das estratégias das organizações jornalísticas em conformidade com os processos de convergência jornalística, com lógica multiplataforma horizontalizada integrando web, tablets, smartphones e versões em PDF e page flip da edição impressa em um continuum multimídia dinâmico. De natureza qualitativa, a metodologia inclui análise dos produtos que se tem como casos empíricos - O Globo a Mais, Estadão Noite e Folha10 -, ancorada em ficha exploratória desenvolvida ad hoc, associada a entrevistas semiestruturadas com editores e repórteres. Os resultados apontam para mudanças no perfil dos profissionais envolvidos com as estratégias de produção para tablets, pela inserção de novos elementos nas narrativas em produtos autóctones. Ao mesmo tempo, identificouse uma transposição 3.0 , visto que o conteúdo exclusivo dos produtos para tablets é posteriormente transposto para outras plataformas.

Palavras-chaves: Convergência jornalística. Jornalismo móvel. Tablets. Produtos autóctones. Estatuto do jornalista. 


\section{LA ACTUACIÓN PERIODÍSTICA EN PLATAFORMAS MÓVILES Estudio sobre productos originales y el cambio en el estatuto del periodista}

RESUMEN - Este artículo se centra en el estudio de carácter empírico y teórico-conceptual de productos originales para tabletas, lanzados como parte de las estrategias de las organizaciones de prensa en conformidad con los procesos de convergencia periodística, con lógica multiplataforma horizontalizada, integrando la Red informática, las tabletas, los teléfonos inteligentes y versiones PDF y Page flip de la edición impresa en un continuo multimedia dinámico. La metodología de naturaleza cualitativa incluye el análisis de productos que se consideran casos empíricos -O Globo a Mais, Estadão Noite y Folha 10- y se basa en una ficha exploratoria desarrollada ad hoc, asociada a entrevistas semiestructuradas con editores y reporteros. Los resultados apuntan a cambios en el perfil de los profesionales involucrados en estrategias de producción para tabletas por la inserción de nuevos elementos en las narrativas en productos originales. Al mismo tiempo, se identificó una adaptación 3.0, ya que el contenido exclusivo de los productos para tabletas es posteriormente adaptado a otras plataformas.

Palabras clave: Convergencia periodística. Periodismo móvil. Tabletas. Productos originales. Estatuto del periodista.

\section{INTRODUCTION}

Within the heterogeneous panorama of implementing convergent "media houses", mobile platforms (smartphones and tablets) are being added to journalistic organisations' operating strategies. Thus, they join the print, radio, television, websites and social networks, giving form to something called the multimedia continuum, in a horizontal and dynamic flow. This idea helps towards understanding the context of journalistic convergence, as it demonstrates that the current logic is not in opposition to the media and its content on other supports.

Barbosa (2013) works on this idea of multimedia continuum, defining it as one of the outlining characteristics of a new evolutionary stage for digital network journalism: the fifth generation. In order to arrive at the proposition of this fifth generation, the author takes the category of mediality as a parameter (GRUSIN, 2010). With this, she indicates that the journalistic production present in various content formats in contemporary times (texts, photos, audio, video, infographics, slideshows, news games and timelines, etc.) created, edited and distributed by journalistic organisations for multiplatforms is carried out entirely by professionals using digital and network technologies. Current production routines presuppose the use of software, databases, algorithms, programming and publication languages, information management systems, visualisation techniques and semantic metadata, etc. Therefore, there is no longer any opposition between old/traditional 
and new media. Mediality explains this panorama more precisely, ending the rhetoric of 'new' and dispersing the incorrect idea of competition between media which form part of the same journalistic multimedia group (BARBOSA, 2013, p. 34).

Alongside mediality, the concept of remediation (BOLTER, GRUSIN, 2000) and "post-remediation" situations operated by digital media, allowing for ruptures and associated to the Database Journalism Paradigm, its categories and functionalities (BARBOSA, 2007, 2009; BARBOSA, TORRES, 2012) and the theory of Journalistic Convergence (GORDON, 2003; DAILEY et al., 2003; QUINN, 2005; LAWSON-BORDERS, 2006; LÓPEZ GARCÍA, PEREIRA FARIÑA, 2010; SALAVERRÍA, GARCÍA AVILÉS, MASIP, 2010; ERDAL, 2011) will assist as references for identifying the fifth generation. The characterising features of this phase can be visualised in the following summarised table, where they are presented next to those representing the third and fourth generations.

Table 1 Characterisation of the evolutionary stages of digital network journalism

\section{Evolutionary stages :: Digital network journalism ::}
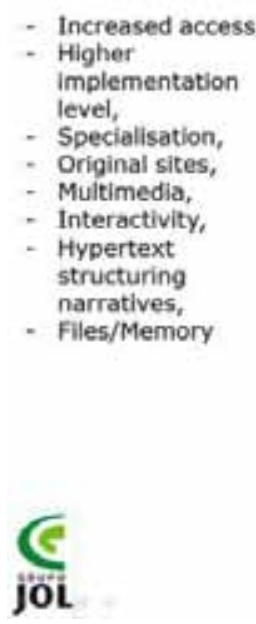

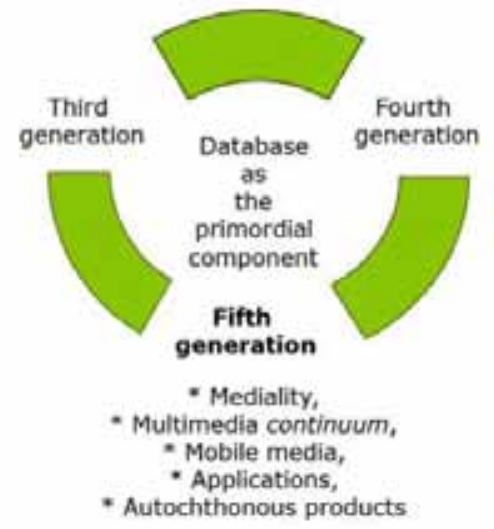

- Dynamic products, - SGC, - Integrated editorial office, - Qualification, - Agility, - Structured information,

- Dynamic narrative. More authentic cybermedia,

- New metaphor, Multiplatform production,

- Smartphones and tablets

Source: Prepared by the author (BARBOSA, 2013) 
According to the table, in this current stage mobile devices are the stimuli for a new cycle of innovation because they will reconfigure the production, publication, distribution, circulation, recirculation, consumption and reception of journalistic content on multiplatforms. In parallel, they will also involve changes in editorial office routines and skills for professionals to work in this environment from which journalistic applications (apps) emerge, especially autochthonous products (original apps for tablets), created in an original format, with exclusive material and a differentiated treatment.

\section{AUTOCHTHONOUS JOURNALISTIC APPLICATIONS}

Journalistic convergence and mobile device journalism embody new dynamics for production processes and new consumption. Westlund (2013) argues for the need to think of a "new journalism model" in view of the culture of mobility established with tablets and smartphone devices and touch screen properties. These last which highlight a new category: tactility, (PALACIOS, CUNHA, 2012) as one of the prominent characteristics for mobile device journalism². These specific characteristics are also explored in a further text (BARBOSA, SILVA, NOGUEIRA, 2012) addressing the idea of autochthonous products (Figure1), defined as applications of an original nature, which are inserted within the modality of investigating resources characteristic of mobile platforms, in terms of navigation, touch interaction and other app particularities.

Figure 1 Covers of autochthonous apps: O Globo a Mais, Estadão Noite and Folha 10

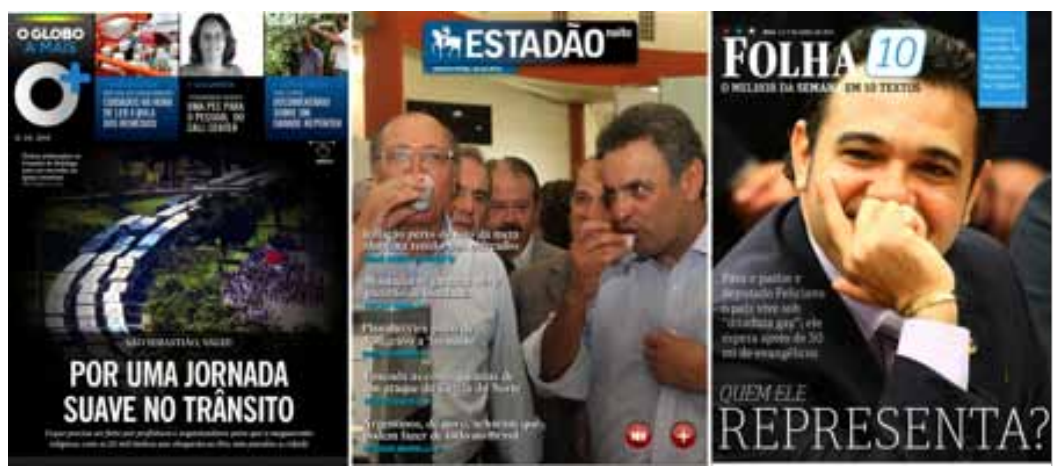

Source: Screen capture 
Therefore we are addressing applications created exclusively for tablets and smartphones, with clear characteristics in specific affordances (MURRAY, 2012) for mobile devices, so that they represent an advanced/distinct stage of PDF versions or construe the printed version as autochthonous products. Considering tactility as one of these affordances (quality or property of the device), autochthonous applications present a format (structure) which incorporates resources such as non-linear navigation, exploring 3D or 360 degree images, work with longer narratives, resources to visualise internal images with a touch of the finger, as well as details for data, numbers and geo-localisation resources, among others.

The emergence of these autochthonous products in journalistic organisations has also marked the appearance of evening editions, which is in tune with the tablet's other affordance: of being a leanback resource, able to capture consumers/readers/users' attention for a longer period of time, unlike lean-forward forms, such as the web, which is more suitable for surfing. Among the examples of evening autochthonous applications, we have Le Soir'17h; O Globo a Mais, which is always published at $6.00 \mathrm{pm}$; Estadão Noite at $8.00 \mathrm{pm}$; Diário do Nordeste Plus at $7.00 \mathrm{pm}$ and La Repubblica Sera at $7.00 \mathrm{pm}$.

Within this perspective of an exploratory and empirical approach, authors such as Scolari, Aguado and Feijóo (2012) have also reflected on the impact of mobile devices by preparing taxonomies as part of their development of a "mobile media theory", involving concepts that consider the mobility phenomenon. However, Güere and Neves (2012), and García (2012) have, in turn, been concerned with developing journalistic applications typologies that represent the nature of mobile devices such as tablets. Included in the typologies are: apps which imitate the paper version and are available in PDF format, apps with a connection to the web version, web apps developed in HTML5 language and already adapted for mobile devices, and original apps, which are created specifically for tablets and smartphones ${ }^{3}$.

\section{METHODOLOGICAL APPROACH FOR THE STUDY}

In order to understand the applications analysed in this article, a better classification of these products is sought, which we considered paradigmatic at the time they were verified (through empirical study), as they form some examples of selected case studies in the national panorama, the first to emerge having been: $O$ Globo a Mais (O Globo), 
launched on January 30, 2012; Estadão Noite (Estado de S. Paulo), launched on April 23, 2012 and Folhal0 (Folha de S. Paulo), launched on July 1, 2012. In the international context, we have further applications of an autochthonous nature or evening editions, such as Krone Zeitung $H D$, created on July 3, 2012 and, the above-mentioned La Repubblica Sera on November 22, 2011, which was a pioneer in the initiative of autochthonous applications for evening editions and whose model was adopted by Globo a Mais.

Of a qualitative nature, the methodology used includes product analysis, incorporating observations on the respective content, based on an exploratory form, developed ad hoc, to evaluate the expression of content in a multiplatform environment in the Laboratory for Convergent Journalism Project (PPP Nº 0060 FAPESB/CNPq), associated to semi-structured interviews with editors and reporters, performed by e-mail between March 11 and April 1, 20134. The interviews sought to capture information regarding the reporters' routines and, therefore, form a picture of their way of dealing with narrative, considering a professional profile adapted to production for tablets with their specific characteristics, described through affordances such as tactility. Similarly, and as a complement, the observation approach was directed at exploring and identifying the elements of application content, in terms of narrative constructions and the resources used and an analysis of the design, based on the characteristics offered by a touch screen and accelerometer interface.

Thus, the questions that guided the empirical study were:

a) How do autochthonous products, with their innovative characteristics, challenge the journalistic production model in a context of convergence based on multiplatforms? and

b) In what way is a journalist's identity and journalistic culture affected by working for emerging mobile platforms?

By construing the problem this way, we sought to outline the characteristics of the products developed within the domain of the respective journalistic organisations and reflect on the work of journalists involved in conducting this process.

In the next section we structure the results of the empirical study from data obtained from the interviews held and from observations, in order to form a picture of how the journalistic organisations in the study act in terms of strategy, and, simultaneously how the profile of these professionals is established, as a result of this new ambience. 


\title{
3 EMPIRICAL STUDY
}

\subsection{Convergent strategies, issues and business models}

In order to analyse the case studies, we also entered into business strategies and models from the initiatives of applications examined from the perspectives of convergence and mobility. In the case of $O$ Globo $a$ Mais, the application was launched based on La Repubblica Sera and other internal research, which indicated a demand for a product with the characteristics of an evening issue and differentiated production from that of the printed PDF version. Estadão Noite, launched at a later date, also used market research as a subsidy. However, Folhalo followed a different model, with a magazine on Sundays, which explored in greater depth the ten themes that had been under most discussion in the newspaper during the week. The editor of $O$ Globo a Mais underlines the strategy for the first evening application in Brazil in the following extract:

\begin{abstract}
As there was no research on tablet readers' behaviour in Brazil, we used American research as a base, which showed the following reading curve: a small amount in the morning, a little reading during working hours and exponential growth from six in the evening. Before the launch we carried out rapid qualitative research with readers who owned tablets at Globo, which showed that they were receptive to a more in depth read in a magazine style at night. However, some also signalled that they would like to read an organised summary of the day and this is why we included an edition of the Giro section, including the main news of that working day. (Maria Fernanda Delmas, interview with the authors).
\end{abstract}

The editor-in-chief for Digital Platforms at Estadão also indicated the use of research as a stimulus for developing Estadão Noite: "Various research surveys - which are public [...] Nielsen, for example, have indicated that reading levels on tablets are higher during the evenings" (Claudia Belfort, interview with the authors). In Folhalo's case, their working strategy is distinct from two other applications mentioned, as they work with logic closer to "packaging" production exclusively for tablets and the product is also distinctive in that it is only distributed in a Saturday/Sunday double edition. The New Platforms editor at Folha de S. Paulo explains:

Generally speaking, there is no report production exclusively for tablets or mobile phones. We believe that we should focus our efforts on having a unified content of Folha distributed and "packaged" in appropriate ways for each platform, instead of segmenting production per platform. (Roberto Dias, interview with the authors) 
In relation to the crossing over among journalistic organisations' platforms, considering the aspect of an integrated editorial office, it was clear that the companies are still trying to consolidate a business model with the applications. The creation of an environment which attracts new readers to the same environment and, as a result, the unification of products in the same application is clearly being sought in the three products analysed. This aim of maintaining and attracting "digital readers" is clear in the $O$ Globo a Mais editor's comments:

The Globo application is a type of unified database for digital tablet products. The printed edition goes online in the morning in a facsimile version. The evening version of $O$ Globo a Mais, which was launched on January 30, 2012, goes online from 6:00 pm. (Maria Fernanda Delmas, interview with the authors)

With regards to the work itself, the editors highlight the investigation of current and factual agendas: "The product line has a large amount of hot content", Maria Fernanda Delmas confirmed, while Claudia Belfort emphasised "temperature and relevance", and Roberto Dias assured that "updating content is valued" even though it is a weekly product. Even when considering the production of special reports in advance, the tendency is to cover that day's events, contextualising, analysing and going into more depth in them, in the three cases analysed (Table 2).

In the course of this article, we argue that autochthonous products are defined as apps created in an original way, with exclusive material and differential treatment, according to the specific affordances (properties) of tablets. As a result of the empirical study, we can illustrate the prominent characteristics of the three products analysed below: $O$ Globo a Mais, Estadão Noite and Folhalo. 


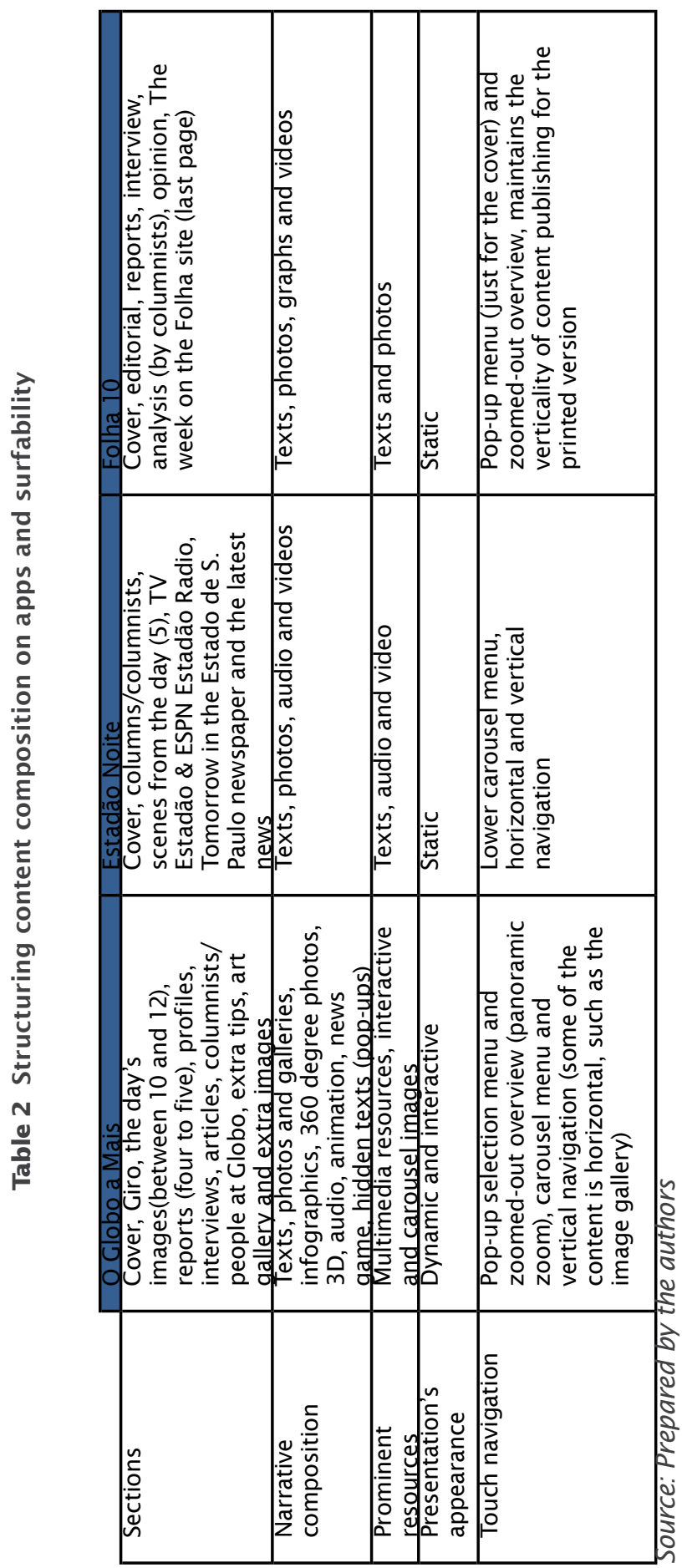


Graph 1 Characteristics of autochthonous applications and models adopted

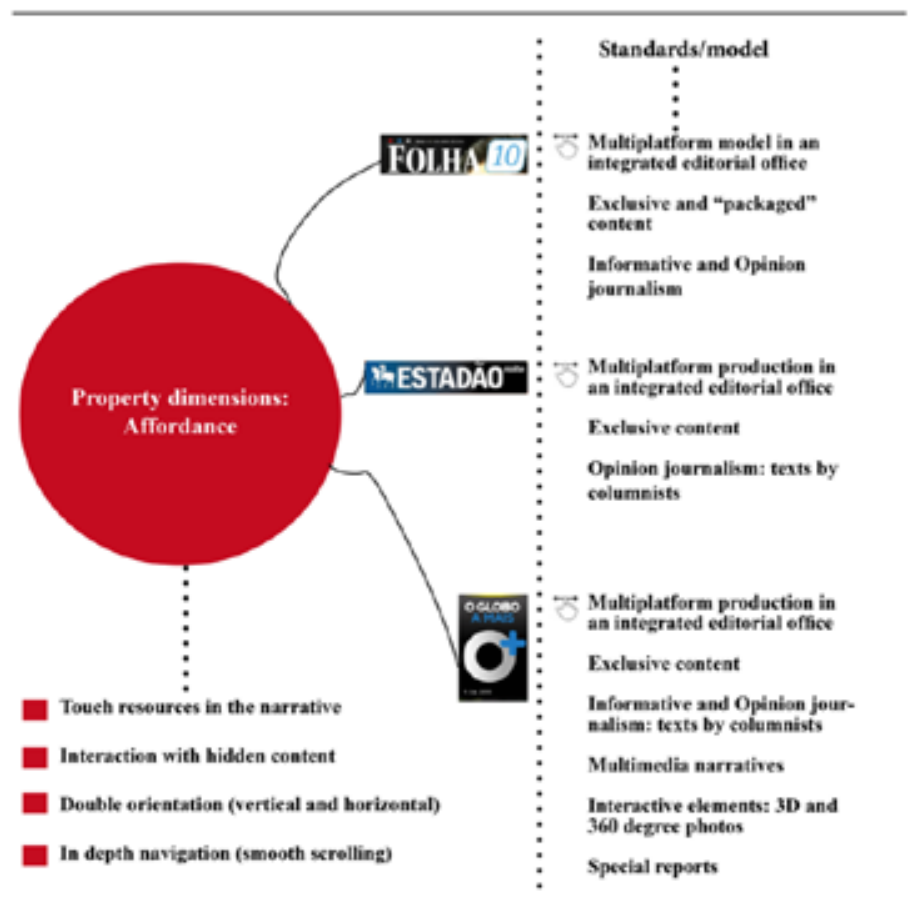

Source: Prepared by the authors

3.2 Production dynamics for autochthonous and touch apps

\subsubsection{Estado de S. Paulo}

It was possible to identify from our interviews that Estadão Noite's production is structured on the concept of journalistic convergence, since the content is not produced by a specific team but by an integrated editorial office. "We have an integrated editorial office and everyone produces for any devices", the editor-in-chief of Digital Platforms, Claudia Belfort explained (interview with the authors). She advised that Estadão Noite has an editor who is responsible for closing the product, accompanied by a designer whose role is to "assemble" the issue.

In the morning version, which replicates the content of the 
printed version of Estadão that day for tablets, there is an editor, who is a journalist and designer and three designers. At Estadão Noite, the routine is established at a $12.30 \mathrm{pm}$ agenda meeting, when the importance and temperature of subjects to define photos and columnists' articles is evaluated, with a $5.00 \mathrm{pm}$ submission deadline set. The editor starts the design after this time and the issue 'goes up' to the App Store at $7.45 \mathrm{pm}$, being available to readers from $8.00 \mathrm{pm}$.

\subsubsection{O Globo}

According to Maria Fernanda Delmas (interview with the authors), the editor of $O$ Globo a Mais, the team comprises three editors, three designers and six reporters 5 . Additionally, the editorial office contributes to some articles, having worked according to an integrated model since 2009. The team concentrates on resources from the platform which may be investigated further in the narrative. "We do a lot of visual material, which can be touched, dragged and expanded and also a large amount of audio. Our principle is to never have an article which just has text and a photo", she advised.

Unlike the other products studied, O Globo a Mais is guided by the premise that all the content published in the tablet version should be new, even if it is replicated on the site or in the printed version the next day. Maria Fernanda Delmas also indicated that the physical interactivity which a tablet allows is the fundamental element for content production. "When we think of a report, we do not imagine just a text, but the 'enrichment' that the subject allows, whether it is the trailer for a film, a photo gallery, an expandable photo or even a news game", she described.

\subsubsection{Folha de S. Paulo}

At Folha de S. Paulo, mobile devices are considered as distribution channels for the newspaper's content. According to the New Platforms editor, Roberto Dias (interview with the authors), there is no report production exclusively for tablets or mobile phones. He also added that ensuring comfortable reading is another principle which directs their work.

Folha10 is produced by just one reporter, Daniela Braga, under Dias' supervision. The mobile device team, which is responsible for the application in HTML5 (for tablets and mobile phones) and Folha10, 
comprises five journalists and includes support from a designer who has other roles at the newspaper, in the printed and online versions.

\subsection{THE JOURNALIST'S PROFESSIONAL PROFILE AND IDENTITY}

Product development for mobile devices signals two main challenges for journalists: 1- How to prepare quality materials swiftly, considering specific affordances for content treatment, while still carrying out meticulous investigations and preserving the ethical principles of the profession; 2- How to present the content, with regards to design, and reinforcing reader interaction. From the reporters' replies on the three products/apps studied, the "time" factor featured among the main challenges.

Autochthonous applications require a focus and narrative which is differentiated from other devices, and that implies different ways of thinking, investigating and structuring articles. There was recognition from the reporters who were interviewed that multimediality and interactivity are fundamental elements when preparing mobile device content.

However, in the interviewees' opinions, the ethical dimension and the profession's deontological codes have not undergone any transformations following new productive routines for mobile devices. "I do not consider that there is a type of ethical behaviour which is related to the new devices. The principles of journalism remain the same" (Flávio Tabak, in an interview with the authors). In the case of the reporters in the exclusive team for the $O$ Globo a Mais application who were interviewed for this study, the view that ethical principles do not change when producing for mobile devices was shared by all.

On being questioned regarding a possible change in journalists' ethical behaviour, within the perspective of mobile production, the reporter from Folha10 argued that "a journalist's ethical behaviour does not change but he should be aware of his conduct when interacting with the reader, especially in heated debates which are common today in blogs and columnists' sections" (Daniela Braga, interview with the authors). The second aspect indicates the importance of the journalist's interaction with the design and programming team in the search for layouts and functionalities which are appropriate for tablets. Despite the reporters who were interviewed recognising that there is a developmental period for a specific narrative for autochthonous products, they indicated that, technically speaking, the applications allow for new experiences and, in 
the functional aspect, communication companies encourage creativity and give freedom for this. That way of thinking, of making news more "attractive" is also shared by the reporters who were interviewed at Globo a Mais, who indicated this aspect as a change initiated by tablet production.

[...] the way that this information is taken has changed so much that we have also been noticing an alteration in how news is "produced". So, my conviction that it has changed a lot comes from the fact that news needs to be more interesting than ever before for readers today. The new media represents a wide range of possibilities, so that someone obtains information. [...] something which offers more interesting information is going to be distinguished from the others -but without leaving relevance, precision and agility by the wayside. (André Miranda, reporter at O Globo a Mais, interview with the authors)

The imagined reader of autochthonous products has a different profile to the reader of other platforms. Firstly, the reader's attention needs to be held, while bearing in mind the range of information, social networks and applications available. Then a reading experience, which is structured on interaction and multimediality, in content with various formats ${ }^{6}$ and a high quality needs to be offered. These are the main inferences that can be drawn from the replies of those interviewed.

As at the journalistic organisations analysed, which have integrated editorial offices, a professional's capacity to adapt texts for each support, while respecting its idiosyncrasies, is reinforced in this setting. Recent research developed by the Post-Graduation Programme in Political Sociology at the Federal University of Santa Catarina, in an agreement with the National Federation of Journalists (MICK, LIMA, 2013), indicated that the professionals who work from 5 to 8 hours correspond to $43 \%$ and from 8 to 12 hours, $40.3 \%$. Also according to the study, which heard 2,731 journalists from all of the States and some based abroad, with spontaneous participation; $76 \%$ of the professionals had all their work or most of it circulated on the internet. This data reinforces the argument of production for multiple supports, integrated editorial offices and the web as a central point in the process of journalistic and media convergence, as it is through a website that multimedia continuum can be visualised or, in other words, on the platforms for which a specific journalistic organisation produces and distributes its content.

In the logic of Bauman's (2007) modern-liquid life, where everything flows and the need for change appears to be the standard, making everything disposable, even identity (in this case, professional) becomes a commodity; the self suffers from saturation (GERGEN apud BURKITT, 2008) and ethical concerns are diluted, in an attempt to survive 
in a society which never stops producing information. With new devices for capturing images and sound, the facilities for publishing a text or transmitting audiovisual productions and also the repercussion of something which is posted on various social network sites, producing content has become an easy task.

However, from the apparent simplicity of this process the complexity of some other questions emerges: 1) What is it like to be a journalist?; 2) What are the attributes which currently define this professional?; 3) What is the role that contemporary society expects him to perform? For Jane Singer (2013, p. 1), mainly observing the aspect of inserting users in the productive process and the role which they also perform of re-circulating journalistic information, "former definitions of a 'journalist' and 'journalism' become less useful" in a contemporary environment, precisely because of the need a professional has to incorporate new forms of communication and elements into his professional culture.

This is reinforced by Christofoletti (2008, p. 94) when he states that "if technology modifies interpersonal relationships, it also changes moral and ethical values. For this reason it is necessary to dwell a little on movements which ruffle the current times, so that we may understand how journalistic ethics are also changing". In an allusion to Foucault, which relates ethical behaviour as the 'practice of freedom' to power relations, Phillips et al. (2010) question: How do power relations operate in news media? What is the level of "domination" or individual freedom? Does the internet environment increase or decrease this freedom for individual journalists? What are the consequences of this for ethical behaviour?

The authors turn to the concept of autonomy in Bourdieu (2005) to defend the idea that journalism is a weak field in terms of autonomy, as freedom depends on an understanding of power sustained in the tension between economic and cultural capital. This tension also accompanies the journalistic universe in the context of production for tablets. The challenge of remaining "sellable" at a time in which there is an excess of information circulating is reflected in the decision to try and make news increasingly attractive.

\section{FINAL CONSIDERATIONS}

The development of autochthonous applications by convergent journalistic organisations in Brazil, European countries, the United 
States and others, is still under development and is an emerging reality, although the products have been available as a business model since the end of 2011. Production for such applications is yet another to add to existing routines and professional culture in editorial offices. As Mark Deuze (2007) points out, the structure of multimedia news organisations emerged in the middle of the 1990s, with companies around the world opting for some form of what he calls cross-media cooperation or synergy between teams, editorial offices and departments which had been formally separate prior to that time.

Of the three cases analysed for this article, only $O$ Globo $a$ Mais, (as it is the only product with a team of editors, reporters and designers formed exclusively for its production) allows us to refine our investigation, in order to situate the journalists' status. While conducting the interviews with the editors, we noted the absence, in some cases, such as Estadão Noite of an exclusive team dedicated to the platform.

This is partly due to the model adopted of favouring analytical articles instead of reports, as is the case for $O$ Globo a Mais. In addition to a group of columnists, it dedicates a part of its editions to reports produced exclusively for tablets. At Folha, the Folhalo app functions as a "snapshot" of the main subjects covered during the week. It has started to add extra multimedia content more recently (essentially photos and videos) as a complement to material which had been static until that time and merely emulated the printed press. While Folhalo is characterised here as an autochthonous product, it is important to point out that it is an autochthonous application for the time being, with a lower level of originality in the content offered and also relating to the treatment given to the material published. Therefore, it complies with the journalistic organisation's strategy which is directed towards multiplying its name in multiplatform products (BARBOSA, 2013).

This preliminary empirical study characterised the differences between products, the types of elements which the properties investigate (affordances) and tablet potential, implications for journalistic routines and, consequently, the professional profile. Specifically with regards to the journalists' profile, from data collected at interviews and on observing the products, the perception is that despite the routine at some points of the production chain resembling that developed in the printed press, transformations in the professional profile result from the dynamics which production for mobile platforms with touch screen interfaces and interactive resources have come to require.

In this sense, the unfolding of storytelling demands more from 
the point of view of design and planning and of thinking about the narrative, while considering the differences in investigating the tablet on its surface, based on tactility. Therefore, journalists' comments (editors and reporters) which were frequent in our interviews, emphatically refer to the need for working more closely with designers and developing skills to understand the resources provided for editing content on mobile applications.

From the results, we also infer an increased value of these new products, in an attempt by communication companies to prepare a new business model in order to: 1.Attract new readers to the group's environment (with the example of $O$ Globo, with the matrix-application bringing together a PDF edition of the morning's printed version, the $O$ Globo a Mais evening issue and $O$ Globo website, with continuous updates. Folhal0also has the same aim of acquiring or maintaining digital subscribers; 2.Produce new profitability (such as Estadão Noite, which is acquired independently to the PDF edition of the printed version). In the case of $O$ Globo a Mais and Estadão Noite, we identified a 3.0 transposition situation, as part of the exclusive content produced is then transferred to the respective communication groups' other platforms, thereby characterizing a reversal of what had previously occurred.

Due to the difficulty in accessing data, such as the number of subscribers for these products, it was not possible to measure the results of the initiatives in terms of "app economics" in company strategies. Furthermore, the emergence of tablet production does not yet allow for conclusive data that would make it possible to unravel the professional profile of the journalists involved or identify the implications for narratives constructed with tablet resources and the cost-benefit ratio for company business models.

\section{NOTES}

1 This research forms part of a wider investigation carried out under the aegis of the Laboratory for Convergent Journalism Project (PPP No 0060, FAPESB/CNPq <http://www.labjorconvergente.info/>), based at the Faculty of Communication at the Federal University of Bahia (UFBA).

2 For Palacios and Cunha, tactility is added to characteristics which have already been investigated in digital network journalism, such as hypertextuality, interactivity, multimediality, personalisation, continuous updates and memory. Therefore, an analysis of mobile platform production considers this specific nature as relevant in the appropriations carried out. 
3 In terms of terminology, García (2012) considers four: native app, HTML5 app, web app and websites optimized for tablets. The differentiation is tenuous in some instances: such as between HTML5 and a web app, while bearing in mind that some web apps are developed in HTML5.

4 Due to the model adopted by companies with regards to their applications, the feedback from interviews was not the same. For the O Globo a Mais application, the strategy was to set up a specific team comprising 3 editors/closers, 3 designers and 6 reporters, in addition to contributions from columnists who alternate during the week, with their own columns. There is a varying position both in Estadão Noite and Folha10. There is no specific team in these cases but, instead, an editor who works on the receipt and selection of production, characterized by a multiplatform and, therefore, resulting from interaction with an integrated editorial office. We also have Estadão Noite, with original content from its columnists. However, in addition to the editor, there is a reporter to complete the team at Folha10. These models had reflections in the feedback from the interviews, as is the case at Estadão, in which we were only able to interview the editor-in-chief of Digital Platforms.

5 Although we sent questions to all of the reporters, we only obtained replies from two of them: André Miranda and Flávio Tabak.

$6 \quad$ We understand the concept of format as structure and a way of presenting narrative based on web and mobile support. Therefore, it concerns the complete structure of a narrative (whether comprising text, photos and interactive timeline), whether as multimedia and interactive infography, data visualization from specific tools, slideshows, videos and audio, etc.

\section{REFERENCES}

BARBOSA, S. "Jornalismo convergente e continuum multimídia na quinta geração do jornalismo nas redes digitais". In: CANAVILHAS, J. (Org). Notícias e Mobilidade. O Jornalismo na Era dos Dispositivos Móveis. Covilhã, PT: Livros LabCOM, 2013. pp. 33-54.

"Modelo JDBD e o ciberjornalismo de quarta geração". In: FLORES VIVAR, J.M.; RAMÍREZ, F.E. (Eds.). Periodismo Web 2.0. Madrid: Editorial Fragua, 2009. pp.271-283.

. Jornalismo Digital em Base de Dados (JDBD) - Um paradigma para produtos jornalísticos digitais dinâmicos. 2007. (PhD Thesis). PostCOM/UFBA. Available at: <http://www.facom.ufba.br/jol/pdf/tese_suzana_ barbosa.pdf>.

BARBOSA, S.; TORRES, V. Extensões do Paradigma JDBD no Jornalismo Contemporâneo: modos de narrar, formatos e visualização para conteúdos. In: Anais XXI Encontro Compós. N. 21, v. 1. Juiz de Fora, MG: UFJF, 2012.

BARBOSA, S.; SILVA, F. F. da; NOGUEIRA, L. Análise da convergência de 
conteúdos em produtos jornalísticos com presença multiplataforma. In: Anais $10^{\circ}$ Encontro Nacional de Pesquisadores em Jornalismo - SBPJor. Curitiba, November 2012. (online), available at: <http://soac.bce.unb.br/ index.php/ENPJor/XENPJOR/paper/view/1888/230>.

BAUMAN, Z. Vida Líquida. Translated by Carlos Alberto Medeiros. Rio de Janeiro: Jorge Zahar Ed., 2007.

BOLTER, J.D.; GRUSIN, R. Remediation: Understanding new media. Cambridge: The MIT Press, 2000.

BOURDIEU, P. "The political field, the social science field and the journalistic field". In: BENSON, R.; NEVEU, E. (Eds.). Bourdieu and the Journalistic Field. Cambridge: Polity, 2005. pp. 29-47.

BURKITT, I. Social Selves. Theories of Self and Society. Thousand Oaks, California: SAGE Publications Inc., 2008.

CHRISTOFOLETTI, R. Ética no Jornalismo. São Paulo: Contexto, 2008.

DAILEY, L.; DEMO, L.; SPILLMAN, M. The Convergence Continuum: A Model for Studying Collaboration Between Media Newsrooms. 2003. (Published in the Atlantic Journal of Communication in 2005. 13(3), 2003. pp. 150-168).

DEUZE, M. Media Work. Cambridge: Polity Press, 2007.

ERDAL, I. J. Coming to terms with convergence journalism: cross-media as a theoretical and analytical concept. Convergence: The International Journal of Research into New Media Technologies. 17 (2), 2011 . pp. 213-223.

GARCÍA, M. iPad Design Lab - Basic: Storytelling in the Age of the Tablet (Kindle Edition), 2012.

GORDON, R. Convergence defined. In: Online Journalism Review. 2003. Available at: <http://www.ojr.org/ojr/business/1068686368.php>. Consulted on March 25, 2013.

GRUSIN, R. Premediation: Affect and Mediality After 9/11. UK: Palgrave Macmillan, 2010.

GÜERE, H.N.; NEVES, Alysson L. Introducción a las Apps de noticias para dispositivos móviles. AE-IC 2012. Available at: <http://www. aeic2012tarragona.org/comunicacions_cd/ok/104.pdf>.

LAWSON-BORDERS, G. Media organizations and convergence. Case Studies of Media Convergence Pioneers.Mahwah, New Jersey: LEA, 2006.

LÓPEZ GARCÍA, X.; PEREIRA FARIÑA, X. Convergencia Digital. Reconfiguração de los Medios de Comunicación en España. Santiago de Compostela: University of Santiago de Compostela, 2010.

MICK, J.; LIMA, S. (Coord). Perfil do jornalista brasileiro. Características demográficas e do trabalho jornalístico em 2012. Florianópolis: Insular, 2013.

MURRAY, J. Inventing the Medium: Principles of Interaction Design as a Cultural Practice. Cambridge, MA: MIT Press. KindleEdition, 2012.

NOGUEIRA, F. J. Autenticidade para Taylor - tensão sobre o papel da individualidade. In: Revista de Filosofia GAMA Digital, 2008.2 edition. pp. $1-12$. 
PALACIOS, M. S.; CUNHA, R. do E. S. da. A Tactilidade in Dispositivos Móveis: primeiras reflexões e ensaio de tipologias. In: Contemporânea, v. 10, n. 3, Sept/Dec 2012. pp. 668-685.

PHILLIPS, A.; COULDRY, N.; FREEDMAN, D. "An Ethical Deficit? Accountability, Norms, and the Material Conditions of Contemporary Journalism". In: FENTON, N. (Ed.). New Media, Old News. Journalism \& democracy in the digital age. London: Sage Publications, 2010.

QUINN, S. Convergent Journalism.The Fundamentals of Multimedia Reporting.New York: Peter Lang Publishing. 2005

SALAVERRÍA R.; GARCÍA AVILÉS. J.A.; MASIP P.M. "Concepto de Convergencia Periodística”. In: LÓPEZ GARCÍA, X.; PEREIRA FARIÑA, X. Convergencia Digital. Reconfiguração de los Medios de Comunicación en España. Santiago de Compostela: University of Santiago de Compostela, 2010. pp. 41-64.

SCOLARI, C.; AGUADO, J. M.; FEIJÓO, C. Mobile media: towards a definition and taxonomy of contents and application. In: International Journal of Interactive Mobile Technologies (iJIM), v. 6, April 2012. Available at: <http://online-journals.org/i-jim/article/view/1880>. Consulted on April 2, 2012.

SINGER, J. User-generated visibility: Secondary gatekeeping in a shared media space. In: New Media \& Society, 0(0) pp. 1-19, 2013.

WESTLUND, O. Mobile news. Digital Journalism. In: Digital Journalism. v.1, no 1, 2013. pp. 6-26. Consulted on February 5, 2013. 
Suzana Barbosa Holds a Doctorate in Communication and Contemporary Culture from the Federal University of Bahia (UFBA). Professor in the Department of Communication and Communication and Contemporary Culture program, Faculty of Communication, at the Federal University of Bahia (UFBA). Investigator-coordinator of the Research Group on Online Journalism (GJOL). Coordinator of the Laboratory of Convergent Journalism Project. E-mail: suzana.barbosa@gmail.com

Fernando Firmino da Silva Holds a Doctorate in Communication and Contemporary Culture from the Federal University of Bahia (UFBA). Professor in the Department of Communication at the State University of Paraíba (UEPB). Contributor to the Research Group on the Cybercity (GPC) and Research Group on Online Journalism (GJOL). Member of the Laboratory for Convergent Journalism Project. E-mail: fernando.milanni@gmail.com

Leila Nogueira Studying for a Doctorate qualification on the Communication and Contemporary Culture program at the Federal University of Bahia (UFBA). Lecturer at the Federal University of the Recôncavo in Bahia (UFRB). Investigator at the Studies in Journalism Centre (NJor) and Research Group on Critical Analysis of the Media and MediaProducts (ANALYTICAL). Member of the Laboratory for Convergent Journalism Project. E-mail: nogueira. leila@gmail.com

Yuri Almeida Studying for a Master's qualification in the Communication and Contemporary Culture program at the Federal University of Bahia (UFBA). Investigator for the Research Group on Online Journalism (GJOL). Member of the Laboratory for Convergent Journalism. E-mail: hdocaos@gmail.com 